\title{
A NeW MEMbER STATE IN THE EU INTERNAL SeCurity System - The Polish Perspective ${ }^{1}$
}

\author{
JERZY MENKES*
}

\begin{abstract}
INTRODUCTION
The aim of the study is to reconstruct the perception of the EU internal security system by Poland, a new Member State, because this perception sets the framework for Poland's participation in cooperation. The starting point of the analysis is a critical evaluation of methods and tools for presenting the non-economic goals of European integration in the acts constituting the institutionalization of cooperation. Criticism is based on the recognition that the way of setting goals applied in the practice of European integration significantly impedes their internalization to a new member, a state which is outside the "old" Europe whereas in accordance with the rules of policyoriented jurisprudence, the awareness of the community of interests by the state determines the effectiveness of the law. The case study of the institutionalization of cooperation is conducted in the interdisciplinary regime (international law and international relations) allowing the learning about the state's conduct.

The conclusions go beyond the Polish perspective; they constitute a generalization of the analysis of norms and facts.

\section{REMARKS ON "SILENT INTEGRATION" OR ON THE DEEPENING THE EUROPEAN INTEGRATION BY EXPANDING ITS SUBJECT RANGE}

\section{On "silence" as a modus operandi (?) of integration}

The Russian proverb "Tishe edesh - dalshe budesh" ("The quieter you go, the further you'll get") conveys the knowledge derived from the experience of generations of subjects that the intents and, even more so,

DOI: $10.1515 /$ wrlae-2018-0026

* Full Professor; Department of International Law and International Organizations, Warsaw School of Economics; menkes.jerzy@gmail.com; ORCID: https://orcid.org/0000-00027744-8167.

${ }^{1}$ This project is funded by National Science Centre of Poland on the basis of the decision No. DEC-2013/11/B/HS4/02126.
\end{abstract}


actions should not be communicated in the undemocratic regimes because the authorities, when notified, may (and often do) take steps to hinder the subject's activity - to prevent the achievement of his goal and punish the independence. The authorities act in this way not because the goal or activity is forbidden by law, but because it is the ruler who has the exclusive power of setting goals (solely the will of the ruler is causative). The subjects are merely the executors of the will and they are not entitled to express (and execute) their own will. Another, although insignificant in the present discussion, ruler-related factor affecting the actions and paralysing the creative activity of the subjects is the pursuit to make the achievement of individual or collective happiness dependent on the ruler's will (that is not subject to legal regulations and hence, in fact, depends on a whim) and not on individual desires and activity. This kind of systemic obstruction by the ruler/authority is a part of a social system of vertical relationships that prevents the rise, or results in the annihilation, of the civil society and, therefore, leads to the undemocratic regime.

The quoted proverb conveys also the knowledge that the most dangerous denouncer of the subject is he himself as any other pawn or element in the undemocratic structure has an interest in keeping the ruler uninformed because drawing his attention to a person results in the ruler's undesired interest in the messenger delivering the unfavourable news.

As it might seem, such a situation is a partial characteristic that only matches a state as described by Gogol. Hence, the thesis that the proverb applies to the recurring events related to the increasing subject range of the European integration and its consequent deepening in the legal regime of the European Union would be even more false or at best surprising.

\section{Road maps of the European integration}

The European integration has a process character with a declarative although markedly general, even vague, end point: "RESOLVED to mark a new stage in the process of European integration undertaken with the establishment of the European Communities, ..., DESIRING to deepen the solidarity between their peoples, (Preamble of the Treaty on European Union) ... This Treaty marks a new stage in the process of creating an ever closer union among the peoples of Europe, (article 1) ${ }^{2}$." The subsequent institutions created for the purposes of European integration, the normative regulations as well as the domains covered, are solely an instrument to reach the goals, whereas the decisions as to their selection are merely a part of the tactic in reaching the goal or the strategy. In a general perspective, the above conclusions seem obvious; nonetheless, each subsequent case implies the, essentially falsely formulated, question of how much tactics and how much strategy it includes. Therefore, the strategic (?) goal of the integration has been, even repeatedly, defined. Its character is that of a norm of European law; however, it is expressed by means of vague concepts or categories using truly Aesopian language and, if that was not enough, both the fundamental stages of accomplishing the goal and its time frame have never been designed and adopted (and undoubtedly formally presented). Needless to say, in

\footnotetext{
${ }^{2}$ http://eur-lex.europa.eu/legal-

content/EN/TXT/HTML/?uri=OJ:C:2010:083:FULL\&from=en
} 
individual cases, the formal stages and time frame of integration were defined (e.g. in the Treaties of Rome establishing the EEC with regards to the common market or in the Lisbon Treaty with regards to the composition and size of the Commission, etc.). Nonetheless, paradoxically, it appears that the formally declared and announced agenda has not been timely implemented in most cases. The fact of the inconsistency between the reality and the announcement has not only been noted, but also certain consequences have been drawn, i.e. the decreased level of detail of the agendas directed by the member states to the EU or, in fact, to themselves, such as in the area of deepening and widening the EU integration, the EU (and its predecessors) constitutes by law a forum for achieving the goals rather than as an actor.

Needless to say, a medium-term and even more so long-term strategy of action in those fields with a high level of aggregation (such as European integration) cannot be defined, as the process related to the plans and agendas displays significant variability. The possible agenda and time frame of integration would, in fact, constitute a forecast and it would be irrational to postulate its legal character or binding effect. A treaty - a norm of the primary law that uses a normative language to define goals and the time frame of their achievement - would be a prescriptive legal act (and thereby close to the Stalinist constitutional model). Every rational agenda is a scenario that may be pursued only to a strictly specified extent defined by the framework of the social reality. One needs to be aware of the fact that pursuing the plans and goals within the political strategy of the European integration does not follow the regime of the rules of playing bridge, a strategic (Bernoulli distribution) game where the victory is the realisation of the "bid contract", and defeat results not only from failing to achieve the determined goal (undertrick), but also from exceeding it (overtrick). In the international reality, the multitude of facts that affect the final result including both the conduct of actors and the events $^{3}$ reduces the efficacy of the deliberate actions. Hence, the actors have a very limited causative power and, consequently, no person or group can act as a demiurge in international relations. However, the fact that the obligation to integrate has the character of a forecast does not explain/justify everything (although it does a lot).

Analysing all instances of delays in the implementation of the European agenda is neither possible not purposeful. Nevertheless, for the sake of illustration, one may point at the case of amending the road map of the Intergovernmental Conference that aimed to review the Treaty of Maastricht pursuant to Article 48 (needless to say, individual cases may not be deemed representative, which disqualifies them as examples). In an official forecast a deeper integration was foreseen in the field of foreign and security policy. After accomplishing the tasks related to the economy, the EU would take steps that would make the European political cooperation the second, similarly strong, pillar of the European structure. Also in this case, it was assumed that the focus would be on one field solely and that the steps would be gradual and taken in stages; however, this did not happen. Undoubtedly, the expectations of deepening integration in the field of foreign and security policy which were addressed at the reviewing conference after Maastricht

\footnotetext{
${ }^{3}$ By these terms, a reference is made to the meaning of concepts of "legal fact", "legal behaviour", and "legal event".
} 
(hopes for the possibility of action related to the peace dividend after the cold war and the annihilation of the Soviet bloc) had to be pushed aside in the face of the challenge of crime unchained with the disappearance of the "iron curtain" that jeopardised internal security ${ }^{4}$.

The unpredictability of the European integration strategy, among other factors, has led to the sense of opacity in the setting/selection of goals, as to which it is not precisely known whether they be strategic or tactical. So far, the highest level of opacity in the social perception of the integration process was reached with the establishment of the European Union by treaty. The negotiating procedure of the Treaty of Maastricht was seen as a result of a secret plot or even the fulfilment of the apocryphal Protocols of the Elders of Zion. Needless to say, such an extreme narrative came from people or parties from the so-called right wing ${ }^{5}$; however, not only from them. The belief that the Treaty of Maastricht was negotiated "in camera, with drawn curtains" was expressed publicly. If so many common people claimed they "had not heard", the counterargument of the authorities that those people "had not been listening" was not a rational one. Needless to say, one may quote the provisions of the Single European Act that clearly and unambiguously announces the future creation of the $\mathrm{EU}^{6}$ but it is not the obligation of the citizens to remember utterances referring to the vaguely specified future. Moreover, there were sufficiently numerous cases of experiences and practices both violating rules and breaching the law (at the conference in Rome, empty sheets were signed instead of the Treaty on EEC; the English and French versions of the Amsterdam Treaty significantly differed; and the very signature had the sole purpose of keeping the deadline, whereas the final negotiations were held after the signing and, in fact, the "consolidated" version included modified and completed the content of the contract) to legitimise a critical assessment of the proceedings conducted by the member states.

\section{DOMAINS OF INTEGRATION - WHY "THESE"?}

The European integration was commenced in the field of economic cooperation, initially involving the abolishing of trade "barriers" between the member states. Its goal was to establish the common market-internal market - single market. This is fundamental knowledge; yet, its obviousness hides the question as to what the "barriers" are. In the most general terms, they are legal instruments of the state's impact on the market which disturbs/ distorts

\footnotetext{
${ }^{4}$ The increase in crime resulted both from the freedom of travelling granted to the citizens of Eastern and Central European states and from the fact that a number of the former interior and defence functionaries joined organized crime; broader J Menkes, 'Od współpracy policyjnej do „przestrzeni wolności, bezpieczeństwa i sprawiedliwości’ (1997) 3 Sprawy Międzynarodowe 59-78; J Menkes, 'Poszerzenie Unii a II i III filar integracji - perspektywy, zagrożenia, warunki' in C Mik (ed), Polska w Unii Europejskiej perspektywy, warunki, szanse, zagrożenia (Torun 1997) 71-93.

${ }^{5}$ Broader on the background of the specific world view of the followers of the "right-wing" opinions see J Haidt, The Righteous Mind: Why Good People Are Divided by Politics and Religion (New York 2012).

${ }^{6} \mathrm{http}: / /$ ec.europa.eu/archives/emu_history/documents/treaties/singleuropeanact.pdf
} 
the market character of the economy. The barriers are against the rules of the market economy and the role of the state in the market (recognized within the market economy), i.e. the role of a judge who watches whether the rules are observed. The barriers disturb/distort the market in which the state claims the role of an almighty causative power ${ }^{7}$. Trade barriers starting with tariffs and quotas are obsolete and primitive tools of affecting economy, increasing the state's income by means of generic tax instruments such as "tax per head", "tax per house" as well as "market rights" and the "Staple". These forms of the state's presence and its interference with the market contradict the very nature of the market economy. Undoubtedly, economic protectionism, the state's over-presence in the market as well as its double role i.e. of the player and of the judge (in the case of a mixed economy with state ownership, the state acts as a judge who participates in the game) that were typical of Western economies after the World War II, constituted the remnants of the challenges related to war and reconstruction (as well as the heritage of the era of 'isms' preceding the outbreak of war). This allows the conclusion that the states, abolishing the barriers in the formula of pursuing a political project, merely anticipated the unavoidable. It is, namely, subject to no doubt that in the reconstructed market economy, the owners would claim economic freedom (just as the French Third Estate claimed political freedom) and that they would be successful in their demands. Liberalising the economic exchange and allowing free and fair trade (Article 3. 5 Treaty on EU), the state abandoned the territory where it used to be a plunderer, undertaking to cease the breaches of rules and questioning the declared constitutional values. In the initial stage of integration, the founding and member states did not integrate or give up anything (in terms of self-restriction in the execution of sovereignty). Therefore, seeking integration in the state's own/proper domain(s) provides a much more interesting challenge ${ }^{8}$.

\section{AREA: INTERNAL SECURITY}

\section{Subject of reflection}

Nominally, the European treaties include extensive normative regulations defining the powers of the EU to act in the field of internal security. The provisions of Article 6 of the Treaty on the Functioning of the European Union (TFEU) constitutes the direct legal basis of the EU powers. At the same time, the procedure of granting the EU the powers in the

\footnotetext{
${ }^{7}$ This role of the state is a part of the cosmological argument (by Aristotle-Aquinas) where the state is the cause of everything that does not have its cause as it is a superior value (The internal contradiction of this argument has been repeatedly pointed out.).

${ }^{8}$ In this respect, there is a profound gap between the will/opinion of the politicians and the opinions/expectations of the citizens. In the Eurobarometer survey of 2012, $92 \%$ of citizens expressed the belief that not all countries have sufficient means to take steps adequate to the needs in the event of a large-scale disaster whereas $82 \%$ of the respondents believed that coordinated crisis management by the EU was more effective than actions taken by individual states; see: 〈http://ec.europa.eu/echo/files/aid/countries/factsheets/thematic/civil_protection_en.pdf> accessed 01.02. 2015.
} 
discussed matter set forth in the normative provisions of Articles 2.5 and 4.1 formulates bans - exceptions and not powers - obligations to act. Needless to say, the normative regulation: "...without thereby superseding their competence in these areas" may be seen first of all as a barrier preventing a negative conflict of competences, i.e. a situation where the the EU has no powers yet, whereas the member state has no powers anymore. Nonetheless, such an interpretation would undoubtedly be an extreme instance of applying the principle of in dubio pro reo. It is more reasonable to conclude that the member states have shown considerable moderation in undertaking international cooperation in the discussed area or, at least, they avoid emphasising such decisions. The latter hypothesis, nota bene in line with the subheading of the present study, is supported by the detailed provisions of the Treaty on the Functioning of the EU.

With this hypothesis in mind, it is difficult to disregard the problems with delimiting the scope, i.e. the set of referents, of the concept of security. In the traditional approach, this concept encompassed the protection of independence and the private interests of the citizens. At times, it has been seen unidimensionally, solely in terms of military or, on the contrary, nonmilitary security ${ }^{9}$. Consequently, on the one hand, it meant self-restriction to perceive security as the capacity of the state defined by the military measures to survive in the anarchist world ${ }^{10}$. In lapidary terms, this view may be reduced to the belief that a secure state does not have to give up its fundamental interests for the sake of protection against aggression and, when attacked, it is capable of defeating the aggressor ${ }^{11}$. This understanding of security constituted a direct response to the belief of Clausevitz that "War therefore is an act of violence to compel our opponent to fulfil our will."12. Security, therefore, is a situation of not being forced to fulfil the will of others. On the other hand, it meant playing down military factors. What may surprise is the fact that the greatest difficulty was to find instances of synthesis of both approaches forming a holistic view of security and considering its consequences $^{13}$.

Nevertheless, these concepts of security deviate from the dichotomous legal division, essential from the perspective of the present reflection, into internal and international security ${ }^{14}$. At the same time, the effects of normative activity display certain ambiguities and inconsistencies as well as the automatism of regulation that is present, not only in the normative acts, but also in academic papers and analyses prepared for the purposes of practical application. In Poland, the concepts of national security, security of

\footnotetext{
${ }^{9}$ For a broader perspective see J Galtung, Peace and Peaceful Means: Peace, Conflict, Development and Civilisation (London 1996).

${ }^{10}$ For a broader perspective see SM Walt, 'The Renaissance of Security Studies' (1991) 35 International Studies Quarterly 212; the security studies were limited to studying threats, use, and control of military power.

${ }^{11}$ W Lippmann, U.S. Foreign Policy: Shields of the Republic (Boston 1943) 51.

${ }^{12} \mathrm{C}$ von Clausewitz, On War, (trans. COL James John Graham, London: N Trübner 1873) http://www.clausewitz.com/readings/OnWar1873/BK1ch01.html.

13 Despite the "archaism" - see Mencius, who considered (internal) social peace as a foundation for the state's potential for defence against external threats.

${ }^{14}$ For a Bronder perspective see R Zięba, 'Po zimnowojenny paradygmat bezpieczeństwa międzynarodowego' in R Zięba (ed), Bezpieczeństwo międzynarodowe po zimnej wojnie (Warsaw 2008) 15-42.
} 
the state, and public security are used interchangeably. As it is indicated, the security of communities and organisations, first of all including that of the state, conditions their existence and development ${ }^{15}$. There is a clear tendency to point to relationships between the sui generis theoretical reflection on security and case studies. Importantly, such a perception of security is echoed by the visible conclusion that identifying and perceiving threats against the state in question forms an important part of the concept of security. A the same time, the historical, economic, and cultural ties as well as axiologies constitute a "core" of the structure of security of the particular, strictly defined, community.

This "local character" of security is, however, not made absolute. It may be noted that the paradigm of the "indivisibility of security" that lays the foundation for idealism and the related solutions in the form of institutionalisation of the "collective security system" has been internalised. It is considered that the risks are common or even single, which allows the conclusion about the emergence of a global pop culture of security.

\section{Internal security}

The European cooperation encompasses also the so called "police cooperation", which in fact has a broader scope "including police, customs and other specialised law enforcement services in relation to the prevention, detection and investigation of criminal offences. For the purposes of paragraph 1, ..., may establish measures concerning: (a) the collection, storage, processing, analysis and exchange of relevant information; (b) support for the training of staff, and cooperation on the exchange of staff, on equipment and on research into crime-detection; (c) common investigative techniques in relation to the detection of serious forms of organised crime" (Article 87, TFEU).

In their cooperation, the EU member states use the institutional support of the EU "in order to improve the effectiveness of systems for preventing and protecting against natural or man-made disasters. Union action shall aim to: (a) support and complement Member States' action at national, regional and local level in risk prevention, in preparing their civilprotection personnel and in responding to natural or man-made disasters within the Union; (b) promote swift, effective operational cooperation within the Union between national civil-protection services; (c) promote consistency in international civil-protection work" (Article 196, TFEU). The cooperation in question, i.e. the EU powers in the discussed area are of subsidiary nature in relation to national actions; the EU does not supersede the state as the entity obliged to carry out its internal functions.

Pursuant to Article 222 of the TFEU, "The Union and its Member States shall act jointly in a spirit of solidarity if a Member State is ... the victim of a natural or man-made disaster. ... The Union shall mobilise all the instruments at its disposal, including the military resources made available by the Member States, to: ... in the event of a natural or man-made disaster."

\footnotetext{
${ }^{15} \mathrm{~S}$ Sulowski, 'O nowym paradygmacie bezpieczeństwa w erze globalizacji' in S Sulowski, M Brzeziński (eds), Bezpieczeństwo wewnętrzne państwa: Wybrane zagadnienia (Warsaw 2009) 12.
} 
Financial measures have great significance for the possibility of tackling the consequences of disasters. The EU provides two types of funds, i.e.: the instruments of economic and social cohesion that may be used to cover risk prevention and restoration of damaged infrastructure and financial means that may be granted to provide financial aid for the regions affected with disasters (primarily natural disasters). The latter enable acting swiftly and efficiently to help and mobilise emergency services "to meet people's immediate needs and contribute to the short-term restoration of damaged key infrastructure so that economic activity can resume in the disaster-stricken regions." To this end, pursuant to Council Regulation (EC) No 2012/2002 of 11 November 2002 establishing the European Union Solidarity Fund, assistance from the Fund may be awarded to a state in the form of a grant that may be used for the purpose of: "(a) immediate restoration to working order of infrastructure and plant in the fields of energy, water and waste water, telecommunications, transport, health and education;(b) providing temporary accommodation and funding rescue services to meet the immediate needs of the population concerned;(c) immediate securing of preventive infrastructures and measures of immediate protection of the cultural heritage;(d) immediate cleaning up of disaster-stricken areas, including natural zones."

\section{Out-of-area action}

Regarding the external actions taken by the European Union, the basis for them is provided by the provisions of Title $\mathrm{V}$ of the Treaty on the European Union (TUE). Article 21 unambiguously declares that the rules of the Union's external action (on the international scene) are in line with principles of European integration. Defining and carrying out common policies and actions, the EU aims at cooperation in international relations, which it regards as an instrument of, among other things, providing aid to nations, states, and regions that are affected by natural or man-made disasters.

Due to the Common Security and Defence Policy (an element of the Common Foreign and Security Policy), the Union possesses operational potential based on civil and military measures. Both types of measures may be used in foreign missions (outside the EU), the so called Petersberg tasks: humanitarian and rescue tasks; - conflict prevention and peace-keeping tasks; - tasks of combat forces in crisis management, including peacemaking; - joint disarmament operations; - military advice and assistance tasks; - post-conflict stabilisation tasks.

Additionally, the EU conducts actions aimed at providing emergency relief, care, and protection to the societies of developing countries that are affected by natural or man-made disasters. Humanitarian actions are carried out in accordance with the principles of impartiality, neutrality, and nondiscrimination.

All forms of the Union's activity in these areas are coordinated with the actions taken by international organisations and bodies (primarily within the system of the United Nations).

The legal framework for the action and cooperation has been defined in the Joint Statement by the Council and the Representatives of the Governments of the Member States meeting within the Council, the European Parliament and the European Commission entitled "The European Consensus on 
Humanitarian Aid"16. The above provisions imply that, notwithstanding general rules on the delimitation of competences, the European legal regulations encompass diverse humanitarian actions in the face of natural and man-made disasters both within the borders of the EU member states and beyond. The proof of the significance of humanitarian actions for the EU and its member states is provided by the appointment of a separate EU Commissioner for Humanitarian Aid and Crisis Management ${ }^{17}$.

\section{Civil Protection}

Since 2001, the EU has been increasing its efforts aimed at coordinating, on the European level, (potential) reactions in the field of humanitarian aid in the face of disasters. The EU provides the possibility of complementing the actions taken by its member states (institutions and government agencies) aimed at in-kind assistance, emergency actions carried out by specialised teams as well as expert support (including assessment of the event and its consequences, or coordination). Institutionalisation of the discussed cooperation takes place in the form of the EU Civil Protection Mechanism ${ }^{18}$. The participating countries include Iceland, Norway and Macedonia, besides the EU member states. The Mechanism enables the coordination of aid provided to the victims of disasters (regardless of their character, both natural and man-made, and the place of event or its consequence, i.e. both in the participating countries and outside their borders). The operational hub of the Mechanism is the Emergency Response Coordination Centre (ERCC) ${ }^{19}$, which constantly monitors emergencies around the globe and coordinates the response of the participating countries in the case of a crisis. The ERCC staff are ready to intervene autonomously (at a relatively short notice) in response to a disaster in the place of its occurrence (taking actions such as search and rescue operations, aerial forest fire fighting as well as medical support ${ }^{20}$. The Mechanism includes also the Common Emergency Communication and Information System (CECIS) that enables communication, as well as tools to monitor events in case of disasters (the CECIS is supervised by the ERCC). In the event of maritime collisions

\footnotetext{
16 [2008] OJ C 25/1

17 However, the mere fact can hardly be seen as constructive as e.g. in the present Commission term, the office is held by Christos Stylianides, a functionary and politician with no relevant experience; a dentist by profession, he acted primarily as a member of parliamentary and quasi-parliamentary bodies whereas his only official experience was the position of the spokesman for the Cypriot government, which he held twice. Without overinterpreting the consequences of such experience (or the lack of others) one may regard this appointment as the expression of perceiving this field as a domain of public relations rather than expected tangible results.

18 Broader <http://ec.europa.eu/echo/en/what/civil-protection/mechanism> accessed 01.02.2015.

${ }^{19}$ It replaced the Crisis Room for humanitarian crises and the Monitoring and Information Centre in 2013.

${ }^{20}$ Since its creation in 2001, the Mechanism has served to monitor over 300 events whereas intervention was carried out in 180 cases, among others after Hurricane Katrina, the Haiti earthquake, a typhoon in the Philippines, and the multi-disaster in Japan in 2011 (simultaneous earthquake, tsunami, nuclear plant failure, power outage, and breaking the supply chain of companies with key meaning for the economy; for broader discussion see: I Krawczyk, 'Kataklizm w Japonii: kumulacja zagrożeń a systemowe rozwiązania (2013) 25 Bezpieczeństwo Narodowe 169, with the cited references.
} 
or disasters bringing about the risk of contaminating the marine environment, the Mechanism cooperates with the European Maritime Safety Agency. The Mechanism constitutes also a formula to institutionalise the cooperation between the states in the area of training relevant services.

\section{Implementation in Poland - a case study}

Poland created a legal framework for the participation of foreign functionaries or employees in joint rescue actions ${ }^{21}$ taking place in Poland based on the Act on Participation of Foreign Functionaries or employees in Joint Operations or Rescue Actions on the Territory of the Republic of Poland (of the $7^{\text {th }}$ of February 2014) ${ }^{22}$. Functionaries or employees of countries covered by the regulation participate in a rescue action carried out by the State Fire Service functionaries ${ }^{23}$. The Act enables, therefore, the participation of foreign units in a multi-entity rescue action. The subject scope of the discussed act, i.e. the premises (circumstances and situations) to apply for the participation of foreign functionaries or employees in a joint rescue action are set forth in Article 3, which contains an enumerative catalogue of six premises for filing the said application:

1) The circumstances justifying joint operation or joint rescue action are of cross-border character;

2) Due to the character of the event justifying joint operation or joint rescue action, the use of internal forces and measures only is impossible or may be insufficient;

3) A large number of foreign citizens is expected to participate in the event justifying joint operation, in particular a mass gathering or a similar event;

4) Due to the character of the event justifying joint operation, in particular a mass gathering or a similar event, the participation of foreign citizens may cause significant threat to public security and order;

5) A joint rescue action is necessary to save citizens' life or health or to prevent a large-scale loss of property;

6) Using forces and measures of a foreign country in a joint action will significantly facilitate the rescue action.

The Act also regulates the rules of coordinating and supervising joint rescue actions. The discussed regulation lays the legal basis for using the work of foreign functionaries and employees as well as vehicles and other means of transportation as logistical support in multi-entity rescue actions conducted on the territory of the republic of Poland, constituting a complex legal tool that adequately matches the needs of services involved in the joint action. The (Polish) statutory and secondary regulations as well as the related practice are coordinated with the norms governing the European cooperation and actions taken within its framework. Pursuant to the National Security

\footnotetext{
21 The Act contains the reference to the definition provided in Article 2.2 of the Fire Protection Act of the $24^{\text {th }}$ of August 1991 (Journal of Laws of 2009, No. 178, Item 1380, as amended).

22 Journal of Laws of 2014, Item 295.

23 Article 1.2 provides for the exception with respect to joint actions coordinated by FRONTEX (European Agency for the Management of Operational Cooperation at the External Borders of the Member States of the European Union) or Maritime Search and Rescue Service.
} 
Strategy of the Republic of Poland, the primary goal and task of the state security policy is the development of the state security system (section 4). The final vision of the state security, as presented in the Strategy, has forced the development of the state's capacity to coordinate and integrate the efforts by various bodies, institutions and government services. In recent years, an integrated, coherent, and structured National Security System of the Republic of Poland has been created, the powers of its elements (e.g. the its managing bodies) have been defined, and the opportunities for interministerial cooperation have been enhanced.

\section{CONCLUSiOnS}

The deepening of the European integration in the field of home affairs may be regarded from two perspectives. One may assess the methods of its implementation, i.e. the degree of observing the rule of law and the principles of democracy. From this perspective, integration may be - at best - seen as a praeter legem activity. On the other hand, integration may be perceived through the prism of the achieved results. From this perspective, a significant and tangible progress of integration may be noted, which allows the increase in the efficiency of expenditure and activity without duplicating efforts and structures.

\section{References}

Menkes J, 'Od współpracy policyjnej do „przestrzeni wolności, bezpieczeństwa i sprawiedliwości’ (1997) 3 Sprawy Międzynarodowe.

Menkes J, 'Poszerzenie Unii a II i III filar integracji - perspektywy, zagrożenia, warunki' in C Mik (ed), Polska w Unii Europejskiej perspektywy, warunki, szanse, zagrożenia (Toruń 1997).

Haidt J, The Righteous Mind: Why Good People Are Divided by Politics and Religion (New York 2012).

Galtung J, Peace and Peaceful Means: Peace, Conflict, Development and Civilisation (London 1996).

Walt SM, 'The Renaissance of Security Studies' (1991) 35 International Studies Quarterly.

Lippmann W, U.S. Foreign Policy: Shields of the Republic (Boston 1943).

Clausewitz C von, On War, (trans. COL James John Graham, London: N Trübner 1873) http://www.clausewitz.com/readings/OnWar1873/BK1ch01.html.

Zięba R, 'Po zimnowojenny paradygmat bezpieczeństwa międzynarodowego' in R Zięba (ed), Bezpieczeństwo międzynarodowe po zimnej wojnie (Warsaw 2008).

Sulowski $S$, 'O nowym paradygmacie bezpieczeństwa $\mathrm{w}$ erze globalizacji' in S Sulowski, M Brzeziński (eds), Bezpieczeństwo wewnętrzne państwa: Wybrane zagadnienia (Warsaw 2009).

Krawczyk I, 'Kataklizm w Japonii: kumulacja zagrożeń a systemowe rozwiązania (2013) 25 Bezpieczeństwo Narodowe. 